Dalacoura, Katerina (2017) US outlook on the Mediterranean. In: Gillespie, Richard and Volpi, Frédéric, (eds.) Routledge handbook of Mediterranean politics. Routledge Handbooks. Routledge, London, UK, pp. 110-119. ISBN 9781138903982

\title{
Chapter 10: US OUTLOOK ON THE MEDITERRANEAN
}

Katerina Dalacoura

There is no unified US outlook on the Mediterranean. The 'Mediterranean' does notappear as a separate region on the State Departmentwebsite and Washington'sthink tanks have few, if any, specialists or publications on the subject as such. Academic and policy output on 'US and the Mediterranean' is scant. The sea where Africa, Asia and Europe converge is crucial for the United States, not least because of the presence of the Sixth Fleet and the existence of close American allies along its north, south, eastand west coasts, such as Spain, France, Italy, Greece, Turkey, Israel, Cyprus, Egypt, Tunisia and Morocco. Vital US interests intersect in the Mediterranean. However, no overarching unifying theme or concept has been offered by American strategists to connect US interests, concerns and policies within itas a geographical space.

Instead of an overarching unifying theme, US foreign policy has traditionally focused on the Mediterranean's sub-regions, namely the eastern Mediterranean, North Africa and southern Europe. It has also centred on a number of issue areas (security, geopolitics, energy, political economy, migration) which are also treated in relative isolation from one another - although I argue in this chapter that the ways in which they are beginning to interconnect may encourage, in future, a more unified US approach and outlook towards the Mediterranean. After a historical overview of US policy towards the Mediterranean, the chapter discusses US policy foreign policy under the Obama administrations. This sets the scene for the core sections of the chapter which examine the two sets or clusters of issues that have preoccupied US policy towards the Mediterranean between 2009 and 2016: security and geopolitics; energy, political economy and m igration . 


\section{Historical overview}

The United States has had a naval presence in the Mediterranean since the early nineteenth century but it was during the early Cold War years that the sea became a focus of US foreign policy and geopolitical concerns. Writing in 1948 on the role of the Mediterranean in American foreign policy, William Reitzel started one of the rare academic books on the subject by stating that 'until very recently the United States had no interest in the Mediterranean that it consciously asserted as vital' (Reitzel, 1948). World War II and the start of the Cold War changed that: Reitzel argues that oil reserves in the Middle East, the need to keep the Soviet Union out of the Mediterranean and the promotion of democracy, as well as the control of the spread of communism, may constitute the main elements of the definition of this interest, 'although there is no consensus on it in American opinion' (Reitzel, 1948: 3). The US Naval Forces Mediterranean were renamed the Sixth Fleet in 1950, with a focus on Africa and Europe. The Fleet was involved in the Lebanon intervention of 1958 and the Yom Kippur War of 1973. There was also a conventional US military presence in Portugal, Spain, Italy, Greece and Turkey (Lesser, 2013). Having said all that, there is a view that in the Cold War the Mediterranean as such was marginal in transatlantic strategic thinking (Lesser, 2013).

One geographical sub-division that prevailed in the US outlook during the Cold War and post-Cold War years was between the eastern and western Mediterranean, with the under- standing that responsibility for the latter would be within the purview of US European allies individually or, later, under the guise of the EEC and the European Union. This is not to say that bilateral relations with the Maghreb countries did not or do not matter for the United States. It has a close and long-standing relationship with Morocco which includes a free trade deal entered into force in 2006; it has also been involved, directly and through the United Nations, in the Western Sahara dispute. Algeria, a Soviet ally during the Cold War, and Libya under the mercurial Muammar Gaddafi, preoccupied the United States because they fed into its Cold War geopolitical calculations. More recently, terrorism and energy have reattracted American interest in the Maghreb, as we shall see later (Lesser, 2009: 21). Nevertheless, there has been an understanding, particularly since the end of the Cold War that the Maghreb is more directly of European concern and 'it is most unlikely that the US will displace European influence in North Africa' (Lesser, 2009:21). 
The eastern Mediterranean is clearly within the purview of the United States, from among the western powers. After the debacle of the Suez War of 1956, Britain and France were ignominiously pushed out from their former areas of colonial influence in the Levant (their more recent involvement tends to be under the guise of the European Union and also in collaboration with Germany and/or other European powers). The Israeli-Palestinian conflict, which has dominated the eastern Mediterranean during the entire post-World War II period, has become during that time more directly of US, rather than European, concern. The US commitment to the defence of Israelis one of the bedrocks of its foreign policy but the Camp David Agreement of 1978 and the Agreement of Principles of 1993 also invested it, at least on one level, in conflict resolution between Israel and the Arabs, and the Palestinians.

Since the end of the Cold War, the Mediterranean has acquired further significance for the United States because of European security and because it is en route to the Gulf, to which it provides an important logistical link. In recent years, US relations with individual southern European countries, Portugal, Spain and Greece, with whom bilateral links used to be more important, have been 'Europeanized', in the sense of them being subsumed under the EU rubric (Lesser, 2009: 5-6). The end of the Cold War removed Soviet containment as one of the two axes of US policy towards the Mediterranean and led to profound changes in US policy towards Europe and the Middle East. Oil remained important but the invasion of Kuwait by Iraq in 1990 and the first Gulf War that followed caused a shift of attention in American policy towards the Gulf, away from the Mediterranean shores. At the same time, the wars of former Yugoslavia focused US activity back to the Mediterranean, with the Sixth Fleet supporting intervention in those wars. Northern and sub-Saharan Africa were part of EUCOM area of responsibility and were tied to the American security presence in Europe; since 2007, except Egypt, they are the responsibility of AFRICOM (Lesser, 2009:11).

The attacks of 11 September 2001 transformed US foreign policy towards the Middle East by drawing the United States more directly into the region, with the focus again being the Gulf. Since the early 2000 s the strength and capabilities of the Sixth Fleet have been reduced. The wars in Iraq and Afghanistan and the 'war on terror' under the influence of neo-conservative ideology defined US foreign policy for a generation and set the scene against which the two Barack Obama administrations constructed American global policies 


\section{The Obama administrations (January 2009-December 2016)}

Barack Obama was elected to the American presidency with a promise to extricate the United States from the Iraq and Afghanistan wars. His pragmatic, realist stance, and his effort to align ends and means in US foreign policy, were in direct and explicit contrast to the idealism of George W. Bush. Obama aimed to 'externalize' the burden of war where vital US interests were not concerned. He chose what has been described as 'surrogate warfare' to deal with the Bush legacy and as an alternative means of maintaining US influence in the Middle East region (Krieg, 2016: 98). The resultant scaling down of the American presence has taken place in parallel with a growing expectation that US dependence on Middle Eastern oil will gradually decrease and enable the United States to further reduce its involvement in the region. The Obama 'pivot' (or rebalancing) to Asia, where more vital US interests lay as China rose, was both a cause and a symptom of the strategic shift away from the Middle East.

Barack Obama laid out in a speech to the United Nations in 2013 his vision of core US interests in the Middle East which he pledged to protect if necessary by military force: 'preventing the spread of nuclear weapons and other weapons of mass destruction; ensuring the unimpeded flow of energy resources to world markets; countering international terrorism; and supporting American allies' (Serwer, 2016: 1). A fifth longer-term objective to be sought through multi- lateral cooperation was 'promoting American values, including democracy, human rights, and open markets' (Serwer, 2016: 1).

For critics, Obama's Middle Eastern policy confirmed a sense of American decline and revealed 'Obama's inability to shape the Middle East' (Gerges, 2012: 11). It also meant the abandonment of US allies and demonstrated Obama's personal failings (timidity, prevarication) (Melhem, 2016). For supporters, it was a necessary readjustment following the destructive over-extension of the Bush years. Either way, US policy caused alarm and disquiet among US allies in the Middle East (notwithstanding the fact that a large part of political and popular opinion in the region had railed for decades against US interference there). It simultaneously disappointed the 'hawks' and the liberal interventionists in Washington who shared the illusion, derived from a fictitious past, that the 
United States would be able to shape or even control events in the Middle East.

In the course of the two Obama administrations, a series of events convulsed the Mediterranean and shaped US policies towards its sub-regions. The 2008-9 global economic crisis and in particular the Eurozone crisis profoundly affected the European Union as a whole and in particular its southern European, Mediterranean flank, Spain, Italy and Greece. The Greek crisis presented a potential existential threat to the Eurozone - and possibly the EU itselfwhich would have had implications for US foreign policy in Europe and beyond. The global and European economic crises were followed by (and to some deg ree may have contributed to) the eruption of the Arab uprisings of 2011 with their complex and varied impact on domestic and regional politics and a toxic mix of war and intervention in the cases of Libya, Bahrain, Yemen and Syria. The turmoil and vacuums of power that followed the uprisings especially in Syria and Libya, as well as the long-term problems in Iraq, led to an upsurge in Islamist extremism, with implications for the entire Middle East, Europe and beyond. With the exception of Tunisia, further authoritarianism, rather than the hoped-for democratization, has been the political outcome of the Arab revolts.

War, instability and repression contributed to a migration crisis of historic proportions in 2015-16, which vitally affected Europe and also drew in the North Atlantic Treaty Organization. Russia, having annexed Crimea and intervened militarily in Ukraine in 2015 , continued in its bid for geopolitical ascendancy by moving southward and entered the Syrian civil war in September 2015 in support of the regime of Bashar al Assad. Last but not least, from 2009 the discovery of large gas reserves in the seabed of the eastern Mediterranean have had consider- able geopolitical implications and affected conflicts and relationships between Israel and its neighbours, in particular Egypt and Turkey; but also the parties to the Cyprus conflict, Greece and Turkey.

\section{Security and geopolitics}

As suggested earlier, the Sixth Fleet is unique in giving a degree of unity to the Mediterranean in US foreign policy. Although the Fleet played a role in the Balkan wars in the 1990s and in particular in the Kosovo intervention in 1999, it has more recently concentrated on supporting American operations in the Middle East and Africa. During the Obama years, the Fleet participated in the Libya intervention of 2011 and carried out 
strikes and supported allied action against al Qaeda and so-called Islamic State (ISIS) in Syria and Iraq. Some of these activities of the Sixth Fleet took place under NATO command. In early 2016, NATO also became involved in salvaging refugees crossing from Turkey to Greece.

Within the context of the crisis unleashed by the post-2011 Syrian civil war, NATO has been called upon to support one its members, Turkey. In 2013 NATO deployed Patriot anti-ballistic missile batteries along the Turkish-Syrian border. NATO has also supported Turkey against Russia in the two countries' rivalry caused by their support of different sides in Syria. Turkey became involved in the Syrian civil war with the aim of removing Bashar al Assad's regime. It supported the Free Syrian Army but, as it was revealed that the FSA was not up to the task, allowed access to al Qaeda offshoot Jabhat alNusra to Turkish soil to bring in arms and fighters. In November 2015 the shooting down of a Russian jet by Turkey raised a worrying prospect of confrontation as NATO rallied to Turkey's support. However, despite US support of Turkey through NATO over Syria, there has also been tension between the two allies: the United States collaboration with the Syrian Kurdish Democratic Union Party (PYD) in the struggle against ISIS alarmed Turkey because of the close PYD-PKK links (Barkey, 2016: 28-9). Russia's growing activities in the Mediterranean constituted a geopolitical concern for the United States. The Soviet Mediterranean Fleet was abolished in 1991 and Russia's Mediterranean Task Force was established in 2013; it is supported by the Black Sea Fleet, one of the four Russian fleets, based in Sevastopol. Russia's only naval base in the Mediterranean is in Tartus, Syria. Safeguarding it was given as one reason for the Russian intervention in Syria in support of the Bashar al Assad regime, but this was probably a side issue.

Syria was a long-standing Soviet and then Russian ally in the Middle East, a vestige of a more glorious past. Through it, Russia is 'returning to the Middle East', though its 'game' is probably being played on a bigger chessboard (Malashenko, 2015). As it is operating on the same side as Iran in Syria, Russia may be rebuilding a regional alliance with it, possibly in an attempt to recapture Cold War relationships (Salem, 2015: 2). The major purpose of Russia's Syrian intervention has been to bolster Russia's bid for global prestige and status and strengthen its geopolitical position in Ukraine, with in Europe, againstNATO. There is even a suggestion, reportedly by a NATO official, that following Russian intervention in Syria, the Mediterranean 'is a contested space again'. According to this 
analysis, Russia's presence south of the Bosphorus is a longer-term and bigger challenge than its intervention in Syria, with the prospect even of complicating US ability to project its naval power as far as the Gulf. NATO has admitted that it has no 'southern strategy' to match the one it has developed in eastern Europe (Jones, 2015). The above is one perspective, however; for others, there is a possibility of Russian and US cooperation in Syria (Rachman, 2016), especially in the light of a common enemy in ISIS. One analyst at least, Thanos Dokos, believes that the return of Russia has been exaggerated as a threat and is doubtful that Russia can become a big player (Thanos Dokos, personal communication April 2016).

The Obama administration has resisted calls for direct intervention in the Syrian civil war but it has supplied arms to the opposition since 2013. From 2014, it has taken part in anti-ISIS strikes there (and in Iraq). The Sixth Fleet is in a supporting role in these attacks in Syria, which are also carried out by drones. The United States has also offered training and equipment to the Iraqi army since the debacle of the fall of Mosul in June 2014 (Dyer, 2016). Ironically, the presence of ISIS in Syria has placed the United States on the same side as Iran and Hizballah, long-standing US rivals in the region. The 2015 nuclear deal with Iran - Obama's major Middle Eastern achievement but a cause of alarm for Saudi Arabia and other regional US allies - has not resolved the confrontation but may help reduce and manage it in the long run.

Obama has tried to extricate the United States from the Iraq and Afghanistan wars with a view to scaling back its involvement in the Middle East, as we saw. This entails local regional powers assuming a bigger role which has indeed happened, with US allies Turkey and Saudi Arabia - as well as smaller powers Qatar and the United Arab Emirates - formulating and executing region-wide foreign policies in pursuit of their interests. Unfortunately, however, the US strategy has led, not to regional power management and stewardship of the problems of the Middle East, but to a power struggle, as Saudi Arabia has pitted itself against Iran and its allies, namely the Iraqi and Syrian governments and Hizballah of Lebanon. This has added fuel to the Syrian civil war and has impacted US concerns in the Levant negatively.

These concerns have ISIS at their core. It is unconvincing to claim that ISIS, since it emergence in 2014, constitutes an existential threat to the United States but it does directly threaten its citizens and assets, and those of its European and Middle Eastern allies. ISIS has 
the potential of drawing the United States back to the Middle East region, something that the Obama administration - having learnt the lesson from the Bush years - has resisted.

North Africa presents a different set of geopolitical and security challenges for US policy in the Mediterranean and the policies it is formulating there are distinct from its interventions in the eastern Mediterranean (although al Qaeda and now ISIS are providing an unwelcome connecting thread between the two sub-regions). 'AI Qaeda in the Islamic Maghreb', one of the al Qaeda 'franchises', has since the mid-2000s constituted a danger to Egypt and Tunisia, both American friends, and contributed to regional instability by attacking Algeria. Tunisia's democratic transition, the only successful outcome of the 2011 Arab revolts to date, is partly threatened by domestic and external Islamist terrorism, and the United States plays a role in supporting Tunis in this struggle (even though its security interests there are not substantial).

The terrorism phenomenon in North Africa is connected to terrorism in the Sahel, to its south. Boko Haram has been active with deadly effect in Nigeria and neighbouring states since the late 2000s. Turmoil and internal conflict in Mali triggered a French military intervention in 2013; Mali continues to be troubled by instability as the terrorist attack in Bamako on 20 November 2015 demonstrated. US concerns in North Africa are even connected, albeit tenuously, to the situation in Somalia, a failed state for a number of years, where the Islamist extremist al Shabaab movement has made a bid for control with an antiwestern and anti-American agenda. Egypt has conventionally constituted a central focus of US policy and it offers a connecting point in the US outlook between North Africa and the eastern Mediterranean, as it straddles both. Egypt has been unstable internally since the 2011 rebellion and this has affected the security situation in its most vulnerable area, which is the Sinai peninsula. A vacuum of power opened up in the Sinaifollowing the overthrow of Mubarak, and fuelled a pre-existing conflict (Middle East Institute, 2014). The troubled Sinai peninsula threatens Egypt and indirectly, because of Sinai's proximity to Gaza, also Israel. It has also given ISIS a foothold and it has vied for power there with aI Qaeda.

The issue in North Africa that has dominated the Obama policies there and in the Mediterranean as a whole has been Libya. Following the outbreak of the rebellion against the regime of Muammar Gaddafi in 2011, NATO (Britain, France, with the United States not taking a front role) intervened in support of the popular forces against the regime; Qatar, 
Jordan and the UAE also collaborated.

Subsequent to the overthrow of Gaddafi, Libya has become effectively a failed state, opening up the opportunity for Islamic extremism to take root. ISIS has found Sirte, in the east of the country, the easiest ground to populate and has sought to push out and dominate other Islamist extremist groups. Obama's complaint in 2016 that Britain and France did not carry their weight in assisting Libya's reconstruction after the Libya intervention of 2011 (Goldberg, 2016) is indicative of the point made earlier, that the United States considers Mediterranean issues, particularly North Africa, as being to a considerable extent the responsibility of Europe. It is illustrative of the general tone and direction of Obama's foreign policy, which rests on burden sharing with US allies. This is in contradistinction to the over-extension during the Bush years but it also has some continuities with past American views in the Mediterranean: one is reminded of Bill Clinton's criticism of Europe not assuming responsibility for the Balkans, its own 'back yard', in the 1990s. The difference is that ISIS has the potential of harming US interests more directly because its power base in North Africa adds to its 'global' presence, so to speak.

North Africa is important for the United States and the European Union because of its energy resources, in particular oil and gas. Alongside Syria and the Middle East, it is the second major route for migrants and therefore a source for the migration crisis which has been unfolding in the Mediterranean with renewed ferocity since 2015. These problems are important in themselves, and will be considered next, but what must be emphasized here is that they inter- link with security issues, especially the threat of terrorism, and therefore shape the US geo- political outlook on the Mediterranean.

\section{Energy, political economy and migration}

The United States does not really depend on the Mediterranean for energy. To put the matter in perspective: in 2014 the United States imported 27 per cent of its needed oil supplies, the lowest percentage since 1985. Twenty per cent of these imports came from the Gulf, primarily Saudi Arabia and Iraq. Having said that, the United States is vulnerable to oil price fluctuations, which are in turn affected by what happens in the Gulf. The American Fifth Fleet is headquartered in Bahrain with a view to safeguarding traffic through the straits of Hormuz (Serwer, 2016:3). When it comes to the Mediterranean, the United States 
acts on the understanding that energy resources and their continuing flow are important to its allies, both Middle Eastern and European. Furthermore, energy sources are intimately linked with a number of conflicts which involve US allies in the Mediterranean.

US energy concerns in the Mediterranean can again be divided geographically into two major sub-regions, the eastern Mediterranean and North Africa. With regard to the former, the Obama administration has been confronted with a rapidly changing situation, which presents both dangers and opportunities. In one analysis, the eastern Mediterranean region 'stands to become one of the world's most important sources of natural gas over the next half century' (Stocker, 2012: 579). The Tamar and Leviathan fields were discovered in 2009 and 2010 respectively in Israeli waters. The Aphrodite field was discovered in Cypriot waters in 2011. Israel and Cyprus stand to gain the most from these finds. Lebanon also has claims on the discoveries (Zhukov, 2013). Some analysts suggest that gas may offer an opportunity for cooperation and the resolution of conflict in the eastern Mediterranean (Gürel and Le Cornu, 2014: 11-33). However, this is an overly optimistic scenario in a sub-region where mistrust is profound and relations are still perceived as zero-sum. In another interpretation, energy resources may serve as objects of future conflicts, rather than a means to sustain old conflicts (Stocker, 2012: 580). Stocker distinguishes between two energy conflicts in the region, the borders of 'exclusive economic zones' of Cyprus, Turkey, Lebanon, Israel, Egypt and an emerging Palestinian state and the future of the pipeline infrastructure (Stocker, 2012: 580). The discovery of energy reserves and the possibility of discovering more has 'revived the question of delineating the exclusive economic zones (EEZs) of all littoral states in the Eastern Mediterranean and added one potential regional dispute' (Grigoriadis, 2014: 124).

The parties to the potential eastern Mediterranean conflicts involving energy, with the exception of the Syrian government, Hamas in Gaza and Hizballah in Lebanon, are US allies. Israel's discovery of the Leviathan gas field has strengthened the possibility of energy selfsufficiency by that country. Lebanon has a potential claim on the gas reserves and the strong position of Hizballah, an enemy of Israel and the United States, in that country complicates the picture. Egypt's discoveries have changed its own foreign policy calculations. The Israeli discoveries have the potential of strengthening its relationship with Cyprus and Greece. With regard to the delivery of gas and the positioning of the pipelines, the fraught relationship between Cyprus and Turkey may prove an obstacle although the 
possibility (in 2016) of a resolution of the Cyprus conflict may transform that particular situation.

The presence of al Qaeda and ISIS in North Africa has increased the risks to the supply of energy, an important consideration for US allies in Europe. Gas and oil reserves are prized possessions which terrorist groups seek to put their hands on. The terrorist attacks in In Amenas in Algeria in January 2013 (where an al Qaeda-linked group demanded the end of French activities in Mali) are an illustration of the interconnections between North Africa and the Sahel security concerns and of how energy and terrorism can become interlinked. ISIS disrupts oil production in Libya to increase the country's instability (in contrast to Syria where its control of oil adds to its coffers and ability to control territory) (Jones and Saleh, 2016).

In its consideration of energy issues in the Mediterranean, the United States has to take into account China's growing role. Christina Lin argues that China 'has entered the Eastern Mediterranean basin and MENA at large by expanding its economic, political, and military footprint'. In light of the perceived waning influence of the US, traditional allies such as Israel and Turkey are upgrading ties with China. In Syria, China supports the Assad regime and has even con- ducted joint naval war games in the eastern Mediterranean with Russia (Lin, 2014a). China's activities in the Mediterranean are propelled by its search for energy resources as well as its push for exports, especially in weapons systems (Turkey and Egypt have turned to China for such sales, which raised alarm bells in the United States). Although some analysts have proposed that China's interest in the Mediterranean may have geopolitical significance for the United States and its allies, China has no obvious strategic concern there. In an alternative interpretation, the presence of China in the Mediterranean can also offer an opportunity for cooperation, rather than strife, with NATO (Lin, 2014b).

War and conflict have caused an unprecedented migration crisis in the Mediterranean since 2015 , ironically an event that has underlined the unity of the sea and the interdependence of its northern and southern, eastern and western shores. The origins of the crisis are not to be found only in the Mediterranean, as those who attempt the crossing come from as far east as Afghanistan and as far south as Somalia. But the Mediterranean is the point at which they all converge to reach Europe, with obvious implications for the European Union and particularly Greece and Italy which are the frontline states. The northern and southern 
shores of the Mediterranean, despite the Eurozone crisis, continue to be separated by a huge gap in living standards and this accentuates the migration crisis. This issue indirectly affects the United States, and NATO forces have played a role, since early 2016, in policing the sea and helping alleviate the humanitarian crisis and prevent the flow of people.

The migration crisis is not linked only to war but also to the wider problems of instability, lack of opportunity and undemocratic government in the Middle East and North Africa. All of these are of some concern to US policy makers, though their ability to shape domestic politics in those countries is in fact quite limited. For example, the role of the United States in the Egyptian uprising and its aftermath has been exaggerated: it did not help overthrow Mubarak or 'abandon' him; it did not support the Muslim Brotherhood in 2012-13. However, the American post-2011 contribution to what appears to be a successful case of democratic transition in Tunisia is a positive one, both bilaterally and through the International Monetary Fund and NATO, which named it major non-NATO ally in 2015.

Finally, the United States, involvement in the Mediterranean occurs within multilateral settings involving mostimportantly its European allies and partners. The Transtantlantic Trade and Investment Partnership (TTIP) negotiations between the United States and the European Union, whose successful conclusion was a major Obama foreign policy objective, are a reason why the Eurozone crisis and the economic situation in southern Europe were of concern to the United States. The United States is still involved in the Balkans through collective arrangements. At the time of writing, in 2016, 680 US troops are still deployed in Kosovo under NATO as part of Kosovo Force (KFOR). Other multilateral arrangements dealing with the Mediterranean which bring together the United States with individual European states and the European Union include NATO's Mediterranean Dialogue which was initiated by the North Atlantic Council in 1994 and involves seven non-NATO Mediterranean states, Algeria, Egypt, Israel, Jordan, Mauritania, Morocco and Tunisia. ${ }^{1}$ The Organization for Security and Cooperation in Europe, which includes 55 states from North America, Europe and Central Asia (OSCE), also comprises a Mediterranean Partnership for Cooperation: the 1975 Helsinki Final Act makes special mention of security in the Mediterranean as being intimately linked to European security (Hauser, 2005: 2-11). ${ }^{2}$ The French-led Union for the Mediterranean which was launched in 2008 as a continuation of the Euro-Mediterranean Partnership also known as the 
Barcelona Process ${ }^{3}$ has 'attracted a surprising degree of attention in Washington' (Lesser, 2009: 8).

\section{Conclusion}

The US outlook on the Mediterranean continues to be fragmented, with Washington treating the various issues that arise in its sub-regions in an ad hoc manner. This is despite the under- standing that the Mediterranean is an important strategic point for the United States, under- pinned by the naval US presence there which provides the capacity for protecting vital US interests, should the need arise, and furthering its goals.

There is an argument (Lesser, 2016b) that terrorism and migration will give the Mediterranean in the near future more weight as compared to the Gulf, with both the EU and NATO looking south where transatlantic interests are engaged more and more. This may mean that the United States will see the Mediterranean increasingly through the lens of its European security interests. It is indeed the case that the growing threats from terrorism and the migration crisis provide a unity to the Mediterranean which has been lacking in the American outlook. The growing presence of Russia and China there may also force Washington to view the Mediterranean with renewed urgency. However, this view is convincing only up to a point.

Terrorism and migration do not threaten vital US interests in the Mediterranean. The Mediterranean would become crucial for the United States only 'by default', so to speak, were its military presence and the security of its allies there to come under threat. This is not likely, particularly given the re-definition of US interests and the scaling down of what constitutes its vital interests. The US policies towards the Mediterranean are affected by the decision in Washington to reduce its military presence in the Middle East 'to correspond to its reduced and shifting interests' (Serwer, 2016: 9). If the trend set by Barack Obama continues in the post- Obama years, we can expect both a 'leaner' US presence in the Mediterranean and a continuing expectation by Washington that its European and Middle Eastern allies should be more active in policing their common interests in the Mediterranean. 


\section{Acknowledgements}

I would like to thank the editors of the volume, Richard Gillespie and Frédéric Volpi; and Thanos Dokos, Spyros Economides and Rachel George for their help. All errors are mine.

\section{Notes}

See www.nato.int/cps/en/natolive/topics_52927.htm (Accessed 12 September 2016).

See www.osce.org/networks/111472 (Accessed 22 September 2016).

See http://ufmsecretariat.org/page/2/?s=united+states\&lang=en\# (Accessed 23 September 2016). 


\section{Bibliography}

Barkey, H. J. (2016) Syria's Dark Shadow Over US-Turkey Relations. Turkish Policy Quarterly, 14(4), 25-36.

Dyer, G. (2016) Iraqi Army Faces Tough Task to Repeat Ramadi Victory over ISIS. Financial Times. 2/3 January.

Gerges, F. (2012) Obama and the Middle East: The End of America's Moment? (New York:Palgrave Macmillan).

Goldberg, J. (2016) The Obama Doctrine. The Atlantic. April Issue. Available at www.theatlantic.com/ magazine/archive/2016/04/the-obama-doctrine/471525/ (Accessed 16 September 2016).

Grigoriadis, I. (2014) Energy Discoveries in the Eastern Mediterranean: Conflict or Cooperation?, Middle East Policy, 21(3), 124-32.

Gürel, A. and Le Cornu, L. (2014) Can Gas Catalyse Peace in the Eastern Mediterranean?, The International Spectator, 49(2), 11-33.

Hauser, G. (2005) The Mediterranean Dialogue: A Transatlantic Approach. Arbeitspapiere zur Internationalen Politik und Außenpolitik. Available at: www.ssoar.info/ssoar/bitstream/handle/document/21843/ ssoar-2005-hauserthe_mediterranean_dialogue_-_a.pdf?sequence=1 (Accessed 16 September 2016).

Jones, S. (2015) Mediterranean Alarm Bells Ring at NATO. Financial Times. 22 October.

Jones, S. and Saleh, H. (2016) ISIS in Libya: Stoking Conflict. Financial Times. 20 March. Available at www.ft.com/content/c06fb0d6-e1f7-11e5-8d9b-e88a2a889797 (Accessed 16 September 2016).

Krieg, A. (2016) Externalizing the Burden of War: The Obama Doctrine and US Foreign Policy in the Middle East. International Affairs, 92(1), 97-113.

Lesser, I. (2009) The United States and the Mediterranean: A New Strategic Context. Mediterranean Academy of Diplomatic Studies. MEDAC Publications in Mediterranean IR and Diplomacy. Summer. Available at www.um.edu.mt/ data/assets/pdf_file/0011/226883/lan_Lesser_MedAgenda.pdf (Accessed 16 September 
Lesser, I. (2013) Strategic Implications and Turmoil in Southern and Eastern Mediterranean: Energy Security and Transatlantic Cooperation. Henry Jackson Society. June 4. Available at http://henryjacksonsociety. org/2013/06/04/strategic-implications-and-turmoil-in-southern-andeastern-mediterranean- energy-security-and-transatlantic-cooperation/ (Accessed 16 September 2016).

Lesser, I. (2016a) NATO Looks South. German Marshall Fund. Available at www.gmfus.org/ blog/2016/02/16/natos-aegean-deployment-shape-things-come (Accessed 16 September 2016).

Lesser, I. (2016b) Israel as a Mediterranean Security Partner. Israeli Mission to the $\begin{array}{llll}\text { European } & \text { Union. Available }\end{array}$ http://embassies.gov.l//eu/NewsAndEvents/Newsletter/Pages//srael-as-a-Mediterranean-SecurityPartner.aspx (Accessed 16 September2016).

Lin, C. (2014a) China's Increasing Role in the Mediterranean. Transatlantic Academy. April. Available at www.transatlanticacademy.org/node/697 (Accessed 16 September 2016).

Lin, C. (2014b) China's Mediterranean Presence is an Opportunity for NATO. Transatlantic Academy.

April. Available at www.transatlanticacademy.org/node/702 (Accessed 16 September 2016).

Malashenko, A. (2015) Russia Returns to the Middle East: Putin's Syria Bet. Le Monde Diplomatique

(English edition), 29 October.

Melhem, H. (2016) Obama's Tarnished Legacy in the Middle East. The Cairo Review of Global Affairs. Winter 2016. Essays. Available at www.thecairoreview.com/essays/obamas-tarnished-legacy-in-themiddle-east/ (Accessed 15 September 2016).

Middle East Institute (2014) Special Feature: A History of Terrorism in Egypt's Sinai, (an interactive guide). Available at www.mei.edu/sinai-terrorism (Accessed 15 September 2016). 
North Atlantic Treaty Organization (2015) Mediterranean Dialogue. Available at www.nato.int/cps/en/ natolive/topics_52927.htm (Accessed 15 September 2016).

Organization for Security and Cooperation in Europe (2016) Mediterranean Partners for Co-operation.

Available at www.osce.org/networks/111472 (Accessed 15 September 2016).

Rachman, G. (2016) Russia and the US Can Deliver Peace in Syria. Financial Times, 3 May. Available at www.ft.com/content/4f3a1e5c-0e01-11e6-b41f-0beb7e589515 (Accessed 15 September 2015).

Reitzel, W. (1948) The Mediterranean: Its Role in America's Foreign Policy (New York: Harcourt).

Salem, P. (2015) Putin Comes to Syria: Contexts and Consequences. Middle East Institute, 21 September. Available at www.mei.edu/content/at/putin-comes-syria-contexts-andconsequences (Accessed 15 September 2015).

Serwer, D. (2016) Recalculating US Policy in the Middle East: Less Military, More Civilian. Middle East Institute. Scholar Series, 'The Middle East and the 2016 Presidential Elections', April. Available at www.mei.edu/sites/default/files/publications/Serwer.pdf (Accessed 15 September 2015).

Stocker, J. (2012) No EEZ Solution: The Politics of Oil and Gas in the Eastern Mediterranean, Middle East Journal, 66(4), Autumn, 579-97. Available at https://muse.jhu.edu/article/489422/pdf(Accessed 15 September 2015).

Union for the Mediterranean, (2016) Website. Available at http://ufmsecretariat.org/page/2/?s=united+ states\&lang=en\# (Accessed 15 September2016).

Zhukov, Y. (2013) Trouble in the Eastern Mediterranean Sea. Foreign Affairs, 20 March. Available at www.foreignaffairs.com/articles/cyprus/2013-03-20/trouble-easternmediterranean-sea. (Accessed 15 Septem ber 2016). 